\title{
Criminal Genomic Pragmatism: Prisoners' Representations of DNA Technology and Biosecurity
}

\author{
Helena Machado ${ }^{1}$ and Susana Silva ${ }^{2}$ \\ ${ }^{1}$ Department of Sociology, Research Center for the Social Sciences (CICS), Institute for Social Sciences, University of Minho, \\ 4710-057 Braga, Portugal \\ ${ }^{2}$ Department of Clinical Epidemiology, Predictive Medicine and Public Health, Institute of Public Health of the University of \\ Porto (ISPUP), University of Porto Medical School, 4050-600 Porto, Portugal \\ Correspondence should be addressed to Helena Machado, hmachado@ics.uminho.pt
}

Received 1 March 2012; Accepted 12 April 2012

Academic Editor: Carlos Ramos

Copyright ( $\odot 2012$ H. Machado and S. Silva. This is an open access article distributed under the Creative Commons Attribution License, which permits unrestricted use, distribution, and reproduction in any medium, provided the original work is properly cited.

Background. Within the context of the use of DNA technology in crime investigation, biosecurity is perceived by different stakeholders according to their particular rationalities and interests. Very little is known about prisoners' perceptions and assessments of the uses of DNA technology in solving crime. Aim. To propose a conceptual model that serves to analyse and interpret prisoners' representations of DNA technology and biosecurity. Methods. A qualitative study using an interpretative approach based on 31 semi-structured tape-recorded interviews was carried out between May and September 2009, involving male inmates in three prisons located in the north of Portugal. The content analysis focused on the following topics: the meanings attributed to DNA and assessments of the risks and benefits of the uses of DNA technology and databasing in forensic applications. Results. DNA was described as a record of identity, an exceptional material, and a powerful biometric identifier. The interviewees believed that DNA can be planted to incriminate suspects. Convicted offenders argued for the need to extend the criteria for the inclusion of DNA profiles in forensic databases and to restrict the removal of profiles. Conclusions. The conceptual model entitled criminal genomic pragmatism allows for an understanding of the views of prison inmates regarding DNA technology and biosecurity.

\section{Introduction}

Physical and biological traces left by the human body can determine whether a person has been in a particular place or in contact with another person or object and may include DNA and fingerprints (trace evidence), iris scanning, photographs, or images on CCTV cameras. Chief amongst these biometric identifiers has been DNA profiling, frequently described as the gold standard for identifying individuals [1] and thus an important tool in crime prevention, detection, and deterrence [2-4]. An increasing number of countries are investing in computerised forensic databases containing a variety of bioinformation, which enables law enforcement agents and forensic experts for instance to compare DNA profiles and fingerprints from crime scenes and subjects on an automated basis.
Due to the high potential of genetic information to provide data that extends beyond the purposes of criminal investigation, the most controversial aspects of forensic DNA databases concern regulatory and ethical issues, leading to the question of the legitimacy, benefits, and risks of using DNA technology in crime prevention, detection, and deterrence. Stakeholders in the field of politics, forensic sciences, and the justice system typically argue that the creation and expansion of DNA databases will help fight crime more efficiently [5], prevent miscarriages of justice [6], and potentially deter offenders from further criminal activity [7]. Some academic researchers (mostly, although not exclusively, in the social sciences and humanities), ethics committees, and human rights groups generally claim that genetic information needs additional protection and argue that criminal investigation activities must be exercised with 
due respect for a number of ethical values, in particular, liberty, autonomy, privacy, informed consent, and equality [8]. Previous literature on prisoners' views of DNA technology and forensic databases indicates that this specific group fears that agents of the criminal justice system do not use this technology in a neutral and fair way [9-12].

Within the context of the uses of DNA technology in crime investigation, biosecurity is, therefore, perceived by different groups according to their particular rationalities and interests [13]. Given the relatively scarce information on prison inmates' perspectives, this paper analyses convicted offenders' representations of DNA technology and biosecurity, aiming to propose a conceptual model that serves to interpret their assessment of the meanings and uses of DNA criminal investigation work.

\section{Materials and Methods}

2.1. Study Design and Participants. A qualitative study was carried out using an interpretative approach. After obtaining authorisation from the Portuguese General Board of Prison Services, 31 semistructured interviews, lasting 34 minutes on average, were conducted with inmates in three prisons for adult males in the north of Portugal between May and September 2009 by three interviewers, all duly trained in accordance with the objectives of the study $[11,14]$. The interviewees were all male, since $94.5 \%$ of all prisoners in Portugal were male at the time the interviews were carried out, according to official statistics provided by the Portuguese General Board of Prison Services on 31 December 2009 [15].

The prison administrators were approached by the research team with a request to provide a list of interviewees. A theoretical sample was devised, based on representativeness in terms of diversity and exemplariness [16], combined with convenience sampling. We interviewed prisoners for whom bioinformation (fingerprints and DNA evidence) had played a role in their criminal investigation and/or trial $(n=$ $7)$, and others for whom this had not been the case $(n=24)$ [10]. Seven of the 31 prison inmates mentioned personal experiences of giving DNA samples. In all cases, it was the police who collected the sample by means of a buccal swab. In two cases, the prisoners stated that the DNA evidence cleared them of rape charges. One prisoner mentioned that a DNA sample had been collected from him by force and one other prisoner stated that he had not consented to the collection of saliva.

The prisoners interviewed were mostly first offenders ( $n=24)$ serving prison sentences for the following crimes: homicide $(n=11)$, rape and/or sexual abuse of minors $(n=8)$, theft $(n=8)$, drug trafficking $(n=4)$, driving without a licence $(n=2)$, and qualified fraud $(n=1)$. The length of the sentences varied from less than 3 years to 25 years. Twenty of the 31 interviewed inmates had been given sentences of 5 to 20 years.

All the prisoners affirmed that they knew what DNA was, although only 22 of the 31 individuals were actually able to spontaneously indicate at least one of the following biological materials as containing DNA: hair, blood, skin, fingernails, and saliva. There were also references to sweat $(n=3)$ and teeth $(n=1)$ as bodily sources of DNA.

2.2. Data Collection. The interview guide contained a list of open-ended questions covering the following themes: (1) knowledge of the uses of DNA technology in criminal investigation; (2) assessment of the benefits and risks of the use of DNA technology by law enforcement agents and forensic experts; (3) opinions on the value of DNA evidence in criminal investigations and trials and its effectiveness in preventing and deterring crime; (4) management of crime scenes in order to avoid leaving traces of a crime; (5) opinions on the criteria for including and removing DNA profiles from forensic DNA databases. For the purposes of this paper, the data relating to the core theme of biosecurity will be discussed by exploring the answers obtained from the following topic questions: "What is DNA?" and "What are the dangers and benefits of the uses of DNA technology and DNA databases in criminal investigation?".

All the interviews were tape-recorded after an informed consent form had been completed by the participants. The interviewees were told that their participation was voluntary; they could refuse to answer any question and could withdraw from the study at any moment. The tapes were transcribed verbatim and the transcripts checked for accuracy. Anonymity was guaranteed through the use of pseudonyms.

2.3. Content Analysis. On the basis of topics previously established in the interview guide and the categories that emerged from the interviews, the central issues and concepts were identified and the data assembled according to thematic categories. Conceptual differences were examined and resolved by further joint debate. The qualitative data was then systematically coded and synthesised around core themes and categories.

The data was analysed based on the model proposed by Williams and Johnson [17] for the conceptualisation of meanings and uses attributed to DNA in forensic applications by the various stakeholders, which is summarised in Table 1.

The data is presented by quantification of the most relevant cases in relation to each topic of analysis and, whenever relevant, by selecting one interview extract that is particularly representative of our qualitative analysis of the discourses produced by the prison inmates.

\section{Results and Discussion}

All the prisoners mentioned that DNA was a powerful identifier that was unique to each individual, but none of them referred to the possibility of identical twins having the same DNA. Although this view corresponds in part to the position of "genomic minimalism" [17], according to which DNA is a mere identifier in itself, the prison inmates expressed concern about the possible uses of this technology as an incriminating tool that could be used by the police to produce evidence against a suspect. 
TABLE 1: Model for conceptualisation of meanings and uses attributed to DNA.

\begin{tabular}{|c|c|c|c|}
\hline $\begin{array}{l}\text { Representation } \\
\text { of DNA }\end{array}$ & Description of DNA & Main agents & Actions \\
\hline $\begin{array}{l}\text { Genomic } \\
\text { minimalism }\end{array}$ & $\begin{array}{l}\text { Mundane identifier, a mere } \\
\text { record of identity }\end{array}$ & $\begin{array}{l}\text { Criminal justice } \\
\text { system, civil servants }\end{array}$ & $\begin{array}{l}\text { Forensic use of DNA as a low } \\
\text { risk/high benefit solution to } \\
\text { criminal detection }\end{array}$ \\
\hline $\begin{array}{l}\text { Genetic } \\
\text { exceptionalism }\end{array}$ & $\begin{array}{l}\text { Exceptional richness of } \\
\text { information }\end{array}$ & $\begin{array}{l}\text { Ethics committees, } \\
\text { human rights groups }\end{array}$ & $\begin{array}{l}\text { Need to regulate its uses in } \\
\text { medicine, insurance and } \\
\text { employment, and in forensic } \\
\text { applications }\end{array}$ \\
\hline $\begin{array}{l}\text { Biometric } \\
\text { pragmatism }\end{array}$ & $\begin{array}{l}\text { Powerful biometric } \\
\text { identifier }\end{array}$ & $\begin{array}{l}\text { Investigators, } \\
\text { criminal prosecutors, } \\
\text { some academic } \\
\text { forensic experts }\end{array}$ & $\begin{array}{l}\text { Exceptionalism is recognised, but } \\
\text { as a resource for fighting crime } \\
\text { rather than a restraint; no need } \\
\text { to classify the information as } \\
\text { requiring unique ethical } \\
\text { treatment }\end{array}$ \\
\hline
\end{tabular}

Source: Williams and Johnson [17].

Sixteen interviewees indicated that DNA databasing of identification would not prevent innocent people from being sent to jail. A group of 11 individuals mentioned that DNA alone cannot be proof of guilt, since DNA traces can be planted at crime scenes by the police in order to incriminate a suspect. As Artur, a prisoner serving a 12-year sentence for burglary and aggravated theft, stated

"The police are quite capable of fabricating evidence to convict someone $(\cdots)$. The technology may be in the wrong hands."

A small number of individuals reported that the power of DNA to identify can be compromised due to laboratory errors $(n=1)$, contamination of samples $(n=3)$, and misinterpretation of results $(n=2)$.

The discourse of the interviewees came close to the position of "genetic exceptionalism" [17] when DNA was seen as a particularly sensitive material, since it is different from any other biometric indicator, such as fingerprinting. Only 2 prisoners mentioned that a DNA analysis can indicate an individual's health status and 1 prisoner expressed concern about the potential abuse of genetic information by insurance companies.

The exceptional nature of DNA was, therefore, conceptualised by the prisoners in a way that was distinctively different from the position held by ethics committees and human rights groups. Whereas the latter groups have emphasised the exceptional information richness of genetic material, the prisoners thought that the exceptional nature of DNA derived from the fact that, in comparison with fingerprints, it is very difficult to avoid leaving DNA at crime scenes $(n=11)$ and although fingerprints can easily be altered with the use of chemicals, surgery, or even third-party fingerprint "theft" $(n=7)$, DNA cannot be altered or falsified.

As Micael, serving a 12-year sentence for rape, stated, it is very difficult not to leave any trace of DNA at the scene of a crime,

"It's, it's very hard not leave any traces. We lose hair every day-and any hair left at the crime scene contains DNA. When we speak we release saliva ... and our bodies are always shedding skin too ... So we always leave some trace behind .... It's not as if you can put yourself inside a bubble and go out and commit a crime, is it?" (cf. Machado and Prainsack [10] p. 132).

All the interviewees expressed a view of DNA technology and its uses in forensic contexts that resembled "biometric pragmatism" [17] in the sense that they agreed with the legitimate and justified use of DNA if this was regulated and confined to the investigation of crime. When referring to criteria for removal of DNA profiles from a forensic database, 20 of the 31 prisoners argued that DNA profiles should never be removed. With regard to the criteria for including DNA profiles in forensic databases, 12 individuals stated that they would agree with the creation of universal databases and 13 mentioned that the criteria for inclusion should be expanded to cover suspects and all convicted offenders. They did not, therefore, agree with the Portuguese law (Law 5/2008 of 12 February) that establishes that only DNA profiles obtained from individuals convicted of serious crimes punishable with an effective prison sentence of 3 years or more are included in the national forensic DNA database.

António, serving a 5-year sentence for drug trafficking, considered that all convicted offenders should automatically have their DNA profiles in the national forensic DNA database,

\section{"All convicted offenders should have their DNA profiles in the national forensic database. I do not understand the logic of only uploading the profiles of offenders who have been given a three- year sentence or more [silence]. What's the logic in giving [pause] some people the right [to be in the DNA database] and not [to] others-if we've all been convicted?"}

In short, the data collected provided information that enabled a new concept to be constructed-criminal genomic pragmatism — and included in the model for understanding 
TABLE 2: Model for conceptualisation of meanings and uses attributed to DNA amongst prisoners.

\begin{tabular}{lll}
\hline Representation of DNA & Description of DNA & Actions \\
\hline Criminal genomic pragmatism & A record of identity & $\begin{array}{l}\text { DNA can be planted to incriminate } \\
\text { Difficult to avoid leaving DNA in crime } \\
\text { scenes } \\
\text { Need to expand the criteria for inclusion of } \\
\text { DNA profiles in forensic databases and to } \\
\text { restrict the removal of profiles }\end{array}$ \\
\hline
\end{tabular}

the specific views of prison inmates on DNA technology and biosecurity (Table 2).

\section{Conclusions}

This paper explores the relationship between biometrics (specifically DNA material) and biosecurity (the risks and benefits of DNA technology) in forensic applications from the point of view of convicted offenders. The prisoners interviewed believe that DNA is a reliable technology for identifying individuals. However, as a social group exposed to the workings of the criminal justice system, they were sceptical of the uses of this technology by the police and the courts, believing, for example, that DNA evidence can be planted at the scene of a crime. This mistrust of the use of technology reflects the results obtained in similar studies carried out in other countries, namely, in Austria and the United States $[9,12,18]$.

The prison inmates have constructed a grounded assessment of biometrics and biosecurity derived from the position they occupy in the real world of crime and criminal investigation. We have termed this criminal genomic minimalism: the prisoners had a practical and grounded vision (pragmatic) based on representations concerning the unique and special nature of DNA (genomic) but which was, above all, the result of direct personal experience of the criminal justice system (criminal), marked by a profound negativity and the feeling that prisoners will always tend to be habitually suspected or arrested in response to crime.

This conceptual model can be applied in future empirical research with convicted offenders to assess how this specific type of biosurveillance can produce effects on the selfmanagement of those whose actions and identities are captured by using DNA technology and databasing in criminal investigation [10]. The knowledge of the possible impacts of DNA technology on the behaviour of criminal actors can be helpful to assist to carry out studies in the following directions: (1) to analyse modalities of the convicted offenders' "forensic awareness" (their awareness of what biological material criminal investigators are able to collect from crime scenes and what inferences can be made from DNA analysis) and if this will or not encourage criminal actors to take additional measures to avoid leaving traces in crime scenes; (2) to evaluate the impact that DNA technologies and DNA databases can have on crime prevention and deterrence (the knowledge of the potential of forensic DNA to assist criminal investigations will deter or not individuals for committing crime); (3) to incorporate the convicted offenders' views in a renewed debate about the balance between imperatives of personal safety, human dignity, and individual privacy on the one hand, and collective security, justice, and equality on the other hand.

\section{Acknowledgments}

The authors would like to thank the Foundation for Science and Technology (Portuguese Ministry of Education and Science) for financing this research through a postdoctoral fellowship (SFRH/BPD/34143/2006) and the "Forensic DNA databasing in Portugal: Contemporary issues in ethics, practices and policy" project (FCOMP-01-0124-FEDER-009231). They are grateful for the insightful and helpful comments of Barbara Prainsack and Manuela Cunha, who provided valuable feedback and guidance throughout the research and in the interpretation of some of the data. They would also like to thank the General Board of Prison Services (Portugal) for their support and Diana Miranda and Filipe Santos for their collaboration in the field work.

\section{References}

[1] M. Lynch, "God's signature: DNA profiling, the new gold standard in forensic science," Endeavour, vol. 27, no. 2, pp. 9397, 2003

[2] A. Bhati, Quantifying the Specific Deterrent Effects of DNA Databases, Justice Policy Center, The Urban Institute, 2010, http://www.urban.org/uploadedpdf/412058_dna_databases .pdf.

[3] M. Briody, The Effects of DNA Evidence on the Criminal Justice Process, School of Criminology and Criminal Justice, Griffith University, 2004.

[4] D. B. Wilson, D. McClure, and D. Weisburd, "Does forensic DNA help to solve crime? The benefit of sophisticated answers to naive questions," Journal of Contemporary Criminal Justice, vol. 26, no. 4, pp. 458-469, 2010.

[5] C. McCartney, "Forensic DNA sampling and the England and Wales National DNA database: a sceptical approach," Critical Criminology, vol. 12, no. 2, pp. 157-178, 2004.

[6] B. L. Garrett, "The substance of false confessions," Stanford Law Review, vol. 62, no. 4, pp. 1051-1119, 2010.

[7] E. Beauregard and M. Bouchard, "Cleaning up your act: forensic awareness as a detection avoidance strategy," Journal of Criminal Justice, vol. 38, no. 6, pp. 1160-1166, 2010.

[8] C. McCartney, R. Williams, and T. Wilson, The Future of Forensic Bioinformation, Leeds, 2010.

[9] T. Duster, "Explaining differential trust of DNA forensic technology: grounded assessment or inexplicable paranoia?" 
Journal of Law, Medicine and Ethics, vol. 34, no. 2, pp. 293300, 2006.

[10] H. Machado and B. Prainsack, Tracing Technologies: Prisoners' Views in the Era of CSI, Ashgate, UK, 2012.

[11] H. Machado, F. Santos, and S. Silva, "Prisoners' expectations of the national forensic DNA database: surveillance and reconfiguration of individual rights," Forensic Science International, vol. 210, no. 1-3, pp. 139-143, 2011.

[12] B. Prainsack, "Partners in crime: the use of forensic DNA technologies in Austria," in Genetic Suspects: Global Governance of DNA Profiling and Databasing, R. Hindmarsh and B. Prainsack, Eds., pp. 153-174, Cambrige University Press, Cambrige, UK, 2010.

[13] F. Lentzos, "Rationality, risk and response: a research agenda for biosecurity," BioSocieties, vol. 1, no. 4, pp. 453-464, 2006.

[14] H. Machado, M. I. Cunha, D. Miranda, and F. Santos, "Stained Bodies: prisoners' perceptions of the DNA database for criminal investigation purposes and their perspectives of social reintegration," 2011, http://dnadatabase .ces.uc.pt/list_documents.php.

[15] DGSP, Existing Inmates on 31 December, According to Education, Sex and Nationality, 2009, http://www.dgsp.mj .pt/backoffice/uploads/anuais/20100302020332RecExist_InstSex-Nac.pdf.

[16] J. Hamel, S. Dufour, and D. Fortin, Case Study Methods, Sage, London, UK, 1993.

[17] R. Williams and P. Johnson, "“Wonderment and dread": representations of DNA in ethical disputes about forensic DNA databases," New Genetics and Society, vol. 23, no. 2, pp. 205-223, 2004.

[18] B. Prainsack and M. Kitzberger, "DNA behind bars: other ways of knowing forensic DNA technologies," Social Studies of Science, vol. 39, no. 1, pp. 51-79, 2009. 



Submit your manuscripts at

http://www.hindawi.com
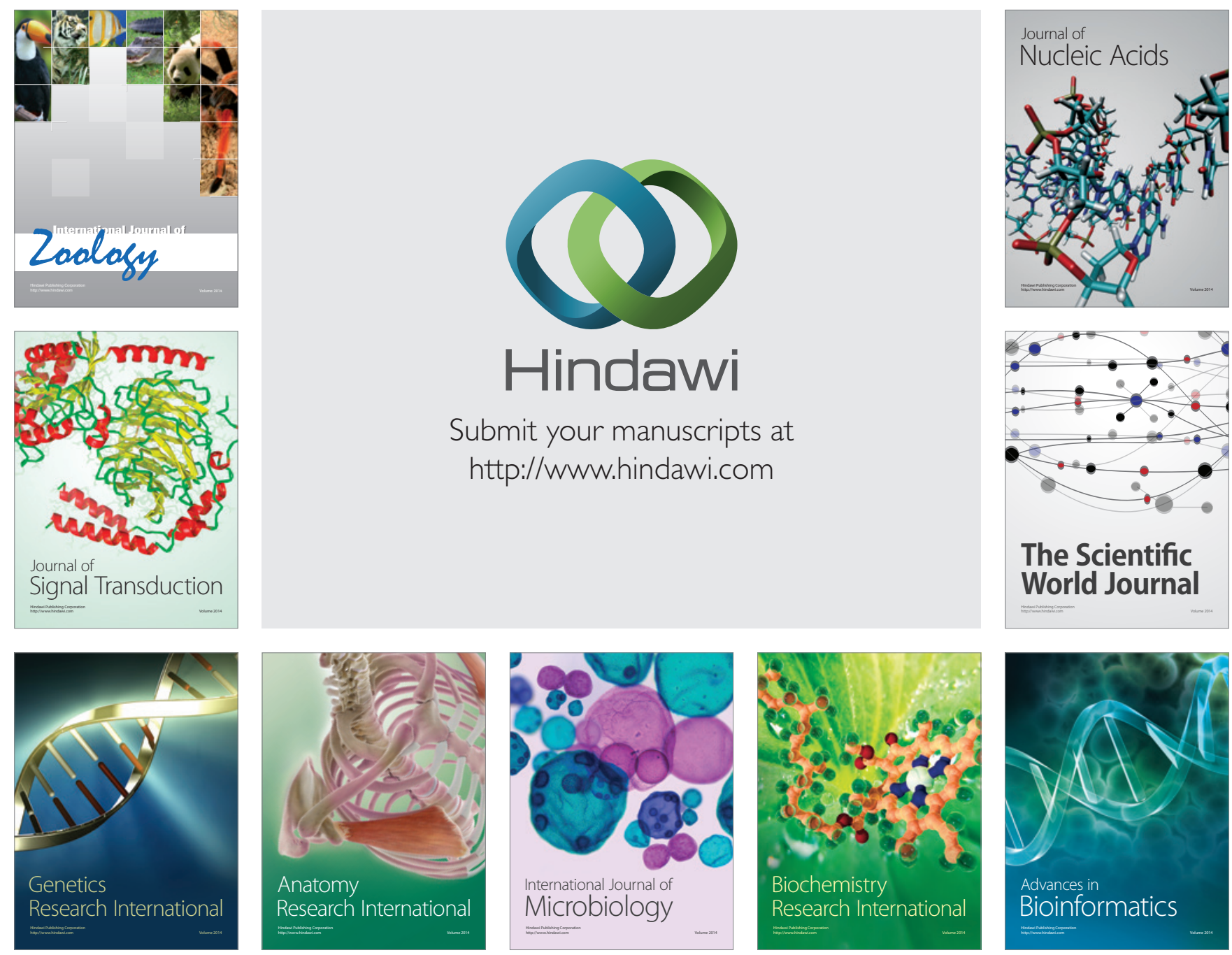

The Scientific World Journal
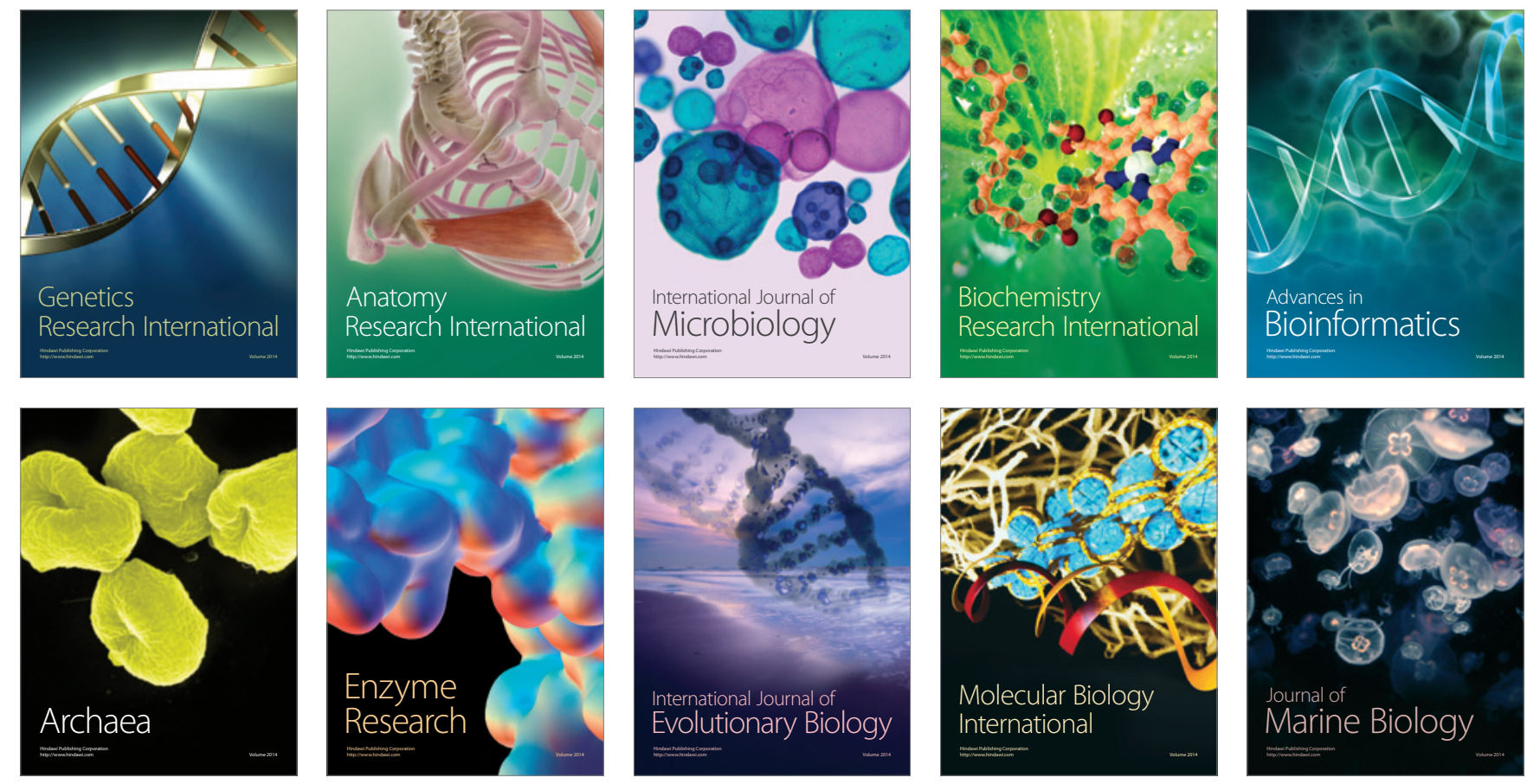